\title{
BITCOIN: A NEW ASSET CLASS?
}

\author{
Rr. Widad Nawa Huwaida \\ Sekolah Tinggi Ilmu Ekonomi Bank BPD Jawa Tengah \\ Email: rrwidadnawa@gmail.com \\ Taofik Hidajat \\ Sekolah Tinggi Ilmu Ekonomi Bank BPD Jawa Tengah \\ Email: inidotcom@yahoo.com
}

Received: October 2019; Accepted: Juni 2020; Available online: July 2020

\begin{abstract}
This study aims to examine the effect of stock prices, exchange rates, and gold prices on the Bitcoin price. The data used are the IDX Composite, the Rupiah/ IDR exchange rate, and the daily gold price from July 19, 2010, to December 31, 2018. Regression equation results show that stock prices, exchange rates, and the gold price had a positive effect on Bitcoin price. Changes will follow changes that occur in stock prices, exchange rates, and gold prices in the price of Bitcoin in the same direction. Bitcoin is considered the same as other assets that are worth having in the investment portfolio.
\end{abstract}

Keywords: stock prices; exchange rates; gold price; Bitcoin.

\begin{abstract}
Abstrak
Penelitian ini bertujuan untuk menguji pengaruh harga saham, nilai tukar, dan harga emas terhadap harga Bitcoin. Data yang digunakan adalah Indeks Harga Saham Gabungan, nilai tukar Rupiah / IDR, dan harga emas harian dari 19 Juli 2010 hingga 31 Desember 2018. Hasil persamaan regresi menunjukkan bahwa harga saham, nilai tukar, dan harga emas berpengaruh positif pada harga Bitcoin. Perubahan yang terjadi pada harga saham, nilai tukar, dan harga emas akan diikuti oleh perubahan harga Bitcoin dalam arah yang sama. Bitcoin telah dianggap sama dengan aset lain dalam portofolio investasi.
\end{abstract}

Kata kunci: harga saham; nilai tukar; harga emas; Bitcoin.

How to Cite: Huwaida, R. W. N., \& Hidajat, T. (2020). Bitcoin: A New Asset Class?. Media Ekonomi dan Manajemen, 35(2), 178-187. doi: http://dx.doi.org/10.24856/mem.v35i2.1223.

\section{INTRODUCTION}

Bitcoin is a cryptocurrency, a digital currency that uses the concept of cryptography as a transaction security system that is attracting attention and is proliferating after the 2008 global economic crisis (Sukamulja \& Sikora, 2018). Through peer to peer networks, cryptocurrency transactions are carried out without requiring the role of a third party as an intermediary. Bitcoin is an interesting phenomenon because it is decentralized, and no regulations are governing it. Until now, many large companies have adopted Bitcoin.

Since 2009, Bitcoin has developed very rapidly. Bitcoin is becoming increasingly popular because of the easy transaction process and no (inexpensive) administrative costs (Sukamulja \& Sikora, 2018). Although the demand for Bitcoin continues to increase, the amount will not be increased because it is only limited to 21 million (Nakamoto, 2008). Such high demand is also influenced by the ac- 
ceptance of several countries that legalize Bitcoin as a means of payment, such as the United States, Japan, and Finland.

Since 2010, Bitcoin has begun to trade and has experienced very significant price spikes. In 2010 the Bitcoin exchange rate of less than USD 1 moved up to USD 1091.44 on December 5, 2013. In early 2016 the value of Bitcoin rose again and reached the highest position of US \$ 19,200 in December 2017.

From the growth and development of the high value of Bitcoin, it can be concluded that the demand for digital currencies is quite high, and many people believe in this digital currency. The massive surge in the price of Bitcoin raises several questions, namely whether the value and Bitcoin transactions will relate to other assets such as gold, stocks to a country's currency.

Some research has been done to find out the relationship between Bitcoin and USD, gold, shares or other assets such as van Wijk (2013), Yermack (2015), Wang, Xue, \& Liu (2016), Kurihara \& Fukushima (2018), Sukamulja \& Sikora (2018) and Smith (2018). However, the findings from some of these studies give different results. For example, Dyhrerg (2016) found that Bitcoin correlates with other assets (Gold and USD) by seeing the higher volatility and return of Bitcoin compared to the two assets. Previously, Whelan (2013) stated that Bitcoin has similarities with USD, which has infinite intrinsic value and is used as a transaction tool. However, this is contrary to the results of Baur's research (2018) which says that Bitcoin is very different and has no relationship with the two assets because the movement of Bitcoin cannot be juxtaposed with the two. Baur also added that Bitcoin is only a place of speculation for investors because of the high value offered.

From some research that has been done, research that examines the relationship between Bitcoin with the Rupiah is also tiny. Therefore, this research was conducted to examine the effect of stock prices, Rupiah exchange rates, and the price of gold on the price of Bitcoin.

\section{LITERATURE REVIEW}

\section{Bitcoin}

Bitcoin is a digital currency that uses the concept of cryptography as a security system (Darmawan, 2014) and becomes an innovation in the financial sector (Sukamulja \& Sikora, 2018). Satoshi Nakamoto introduced Bitcoin in 2008 through an article entitled '"Bitcoin: A peer-to-peer Electronic Cash System." In his journal, Nakamoto (2008) discusses the weaknesses of electronic payment systems, namely the high transaction costs. He believes that by using a peer to peer network in an electronic payment system, there is no need for a third-party role.

Unlike conventional currencies, the mechanism to get bitcoin is through mining, exchange, and faucet. The mining mechanism is quite tricky because miners have to solve the algorithm in a limited amount of time. If miners can solve the algorithm, they will get a reward in the form of bitcoin.

The second way to get Bitcoin is through the Bitcoin trade exchange is an easy way. Buying and selling Bitcoin is done through an online exchange. In Indonesia, buying and selling Bitcoin and other cryptocurrencies can through Indodax. The third way is through the faucet. Some sites provide free Bitcoin, which is by fulfilling specific tasks or requirements, such as watching advertisements, answering surveys to downloading applications.

\section{Previous research}

Although it is a relatively new phenomenon, there has been much research on Bitcoin. Here is some research to see the relationship between Bitcoin and other assets (Table 1). 


\section{BITCOIN}

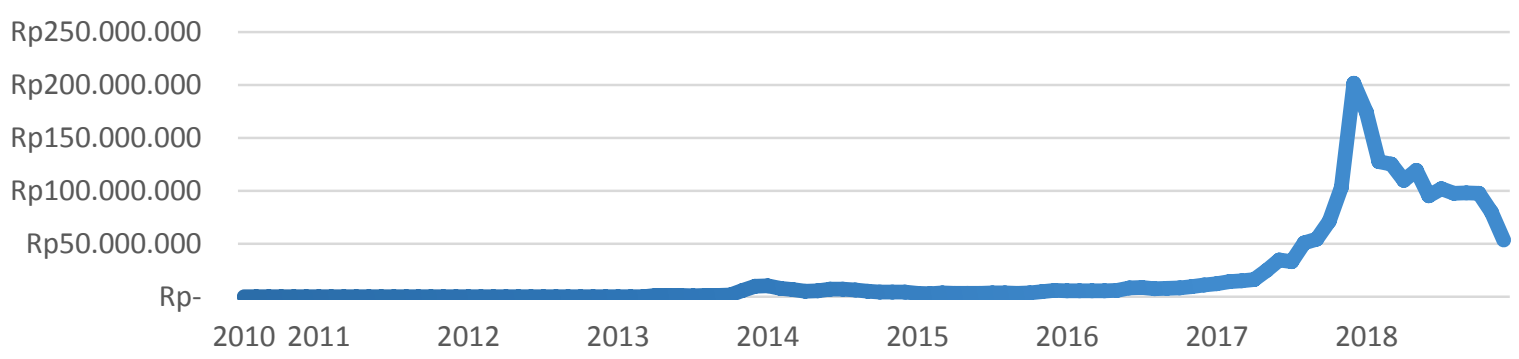

Figure 1. Bitcoin Prices for 2010 - 2018

Source: $\underline{w w w . c o i n d e s k . c o m}$

Table 1. Previous Research

\begin{tabular}{|c|c|c|}
\hline Reseach & Variable & Conclusion \\
\hline van Wijk, 2013 & $\begin{array}{l}\text { - Bitcoin price. } \\
\text { - Dow Jones, FTSE } 100 \\
\text { and Nikkei } 225 . \\
\text { - USD, EUR, JPY } \\
\text { - Brent, West Texas } \\
\text { Intermediate (WTI) } \\
\text { dan Constant Maturity } \\
\text { Commodity Index } \\
\text { (CMCI) }\end{array}$ & $\begin{array}{l}\text { - Dow Jones has a significant positive } \\
\text { effect on the value of Bitcoin both in the } \\
\text { long and short term. } \\
\text { - EUR / USD and WTI Oil Prices have a } \\
\text { significant adverse effect on the value of } \\
\text { Bitcoin in the long run } \\
\text { - EUR / USD and JPY / USD have a } \\
\text { positive effect on the value of Bitcoin in } \\
\text { the short term } \\
\text { - Nikkei } 225 \text { has a significant adverse } \\
\text { effect on the value of Bitcoin in the short } \\
\text { term } \\
\text { - FTSE 100, Brent Oil and CMCI do not } \\
\text { affect the value of Bitcoin, both in the } \\
\text { long and short term }\end{array}$ \\
\hline Yermack & $\begin{array}{l}\text { - Bitcoin } \\
\text { - EUR, JPY, CHF, GBP } \\
\text { - Gold price. }\end{array}$ & Exchange rates and gold hurt bitcoin. \\
\hline $\begin{array}{l}\text { Wang, Xue, \& } \\
\text { Liu, } 2016\end{array}$ & $\begin{array}{l}\text { - Price of Bitcoin } \\
\text { - Stock Price Index } \\
\text { - Crude Oil Prices } \\
\text { - Trading Volume }\end{array}$ & $\begin{array}{l}\text { - Stock price indexes, oil prices, and } \\
\text { trading volumes affect the price of } \\
\text { Bitcoin in the long run } \\
\text { - Stock price indexes and oil prices have a } \\
\text { negative effect on bitcoin prices (when } \\
\text { prices increase) } \\
\text { - Daily trading volume has a positive effect } \\
\text { on the price of bitcoin }\end{array}$ \\
\hline Dyhrberg, 2016 & $\begin{array}{ll}\text { - } & \text { Bitcoin } \\
\text { - } & \text { Gold Cash \& Gold } \\
& \text { Future } \\
\text { - } & \text { FTSE } \\
\text { - } & \text { USD, EUR, GBP }\end{array}$ & $\begin{array}{l}\text { - The price of gold, FTSE, and exchange } \\
\text { rates affect Bitcoin. } \\
\text { - Bitcoin has several similarities with gold, } \\
\text { namely good hedging ability, reacts to } \\
\text { good and bad news in the short term and } \\
\text { can be used as portfolio management, risk } \\
\text { analysis, and market sentiment. }\end{array}$ \\
\hline
\end{tabular}




\begin{tabular}{|c|c|c|}
\hline Reseach & Variable & Conclusion \\
\hline $\begin{array}{l}\text { Kurihara } \quad \& \\
\text { Fukushima, } \\
2018\end{array}$ & $\begin{array}{l}\text { - } \text { Price of Bitcoin } \\
\text { - } \text { JPY, USD } \\
\text { - } \text { Nikkei } 225\end{array}$ & $\begin{array}{l}\text { - JYP / USD does not affect Bitcoin Price } \\
\text { Volatility } \\
\text { - Nikkei } 225 \text { does not affect Bitcoin Price } \\
\text { Volatility } \\
\text { - There is a difference between short-term } \\
\text { volatility and long-term volatility in } \\
\text { Bitcoin prices }\end{array}$ \\
\hline $\begin{array}{ll}\text { Sukamulja } & \& \\
\text { Sikora, } 2018 & \end{array}$ & $\begin{array}{l}\text { - Price of Bitcoin } \\
\text { - Dow Jones Industrial } \\
\text { Average } \\
\text { - Bitcoin requests } \\
\text { - Bitcoin offers } \\
\text { - Gold price }\end{array}$ & $\begin{array}{l}\text { - DJIA has a significant negative effect on } \\
\text { the price of bitcoin in the long and short } \\
\text { term } \\
\text { - The price of gold has a negative effect on } \\
\text { the price of bitcoin in the short term } \\
\text { - Bitcoin offers do not affect bitcoin in the } \\
\text { long term but do affect the short term } \\
\text { - Bitcoin requests have a significant } \\
\text { negative effect on the long and short term }\end{array}$ \\
\hline Smith, 2018 & $\begin{array}{l}\text { - } \text { Price of Bitcoin } \\
\text { - USD, GBP, JPY and } \\
\text { CHF }\end{array}$ & $\begin{array}{l}\text { - The exchange rate does not correlate with } \\
\text { the price of Bitcoin. }\end{array}$ \\
\hline
\end{tabular}

\section{Research Hypothesis}

The stock price index is an indicator that shows the movement of stock prices, where each movement will indicate changes in the market situation that is happening. According to Wang et al. (2016), the index can reflect the level of macroeconomic and financial growth. Theoretically, when economic conditions are right, stock prices will increase.

Bitcoin is a new financial instrument and an alternative investment (Sukamulja \& Sikora, 2018). However, according to Kristoufek (2015), the price of bitcoin cannot be explained by classical economic theories such as cash flow, purchasing power, and interest rates because the bitcoin market does not have a standard supply and demand balance point.

Kurihara \& Fukushima (2018) stated that the stock index does not affect the price of Bitcoin because the price of bitcoin is purely based on market demand and supply and has nothing to do with the stock market. However, this contrasts with Sukamulja \& Sikora (2018), van Wijk (2013), and Wang et al. (2016) which states that macroeconomic indicators and stock indexes hurt Bitcoin prices.

Similar to bitcoin, the exchange rate is also determined by how much demand and offer of the currency is. If demand is higher than demand, it will experience appreciation. Vice versa, if the demand is smaller than the offer, there will be depreciation.

Dyhrberg (2016) shows that the exchange rate (USD) affects the price of bitcoin because bitcoin reacts to fed interest rates and can handle risks better than the United States dollar. It is in line with van Wijk (2013) and Yermack (2015), which mentions that the exchange rate harms the price of bitcoin. On the other hand, Kurihara \& Fukushima (2018) states that the exchange rate does not affect the price of bitcoin because bitcoin is only an arena of market speculation that has enormous volatility.

Gold is one form of investment that tends to be risk-free (Murtini, et al., 2001). Gold is one of the investment assets that is always juxtaposed with bitcoin because it has similarities. Thus, the price of Gold is 
considered to be one of the factors affecting the price of bitcoin (Sukamulja \& Sikora, 2018). In research, Dyhrberg (2016) states that Gold affects bitcoin. On the other hand, research Baur, Dimpfl, \& Kuck (2018), Sukamulja \& Sikora (2018), Zhu, Dickinson, \& Li (2017) and Yermack (2015) states that Gold negatively affects bitcoin, because if there is a change in the price of Gold, it will affect bitcoin volatility.

Based on the explanation above, the hypothesis in the study is as follows:

$\mathrm{H} 1$ :Stock prices affect the price of Bitcoin.

H2: IDR / USD exchange rate affects the price of Bitcoin.

H3: The price of Gold affects the price of Bitcoin.

\section{RESEARCH METHODS}

The data used is the Indonesia Composite Index as a proxy of stock prices, the exchange rate of the Rupiah against the USD, the price of gold and the price of Bitcoin for the period 18 July 2010 to 31 December 2018 on weekdays. The sampling technique for retrieving data is purposive sampling. Purposive sampling is how to choose a sample using specific criteria. The criteria used in this study is the period since Bitcoin began frequently trading until the end of 2018. Each of these data is taken from www.idx.co.id, IDR/ USD exchange rate (www.bi.go.id), gold price (www.investing.com) and bitcoin price (https://charts.bitcoin). com) in the period 19 July 2010 - 31 December 2018 (Figure 1).

The analytical tool used is multiple linear regression. The dependent variable is the price of bitcoin, while the independent variable is the stock price, the exchange rate, and the price of gold.

\section{RESULT AND DISCUSSION}

\section{Normality test}

The results of the normality test using P-P Plot show that the data are not generally distributed because there are still deviations from the diagonal line (Figure 2). The same results were shown in the Kolmogorov-Smirnov test. The Kolmogorov-Smirnov test results in Table 3 show a significant value of 0.000 which is smaller than 0.05 so that Ho is rejected or the data are not normally distributed. Because of this, some outlier data will be issued.

Kolmogorov Smirnov test results in Table 4 showed a significance value of 0.008 , which is very far below 0.05 . By looking at the residual distribution patterns, the regression model has not been normally distributed (Figure 3). For this reason, the data is transformed into $\mathrm{Ln}$ forms, and some outlier data will be excluded from the analysis.

The results of testing with the second P-P plot show the data deviation is smaller than the diagonal line so that it can be concluded that the data is normally distributed. Whereas the Kolmogorov Smirnov test results continue to produce data that is not normally distributed. According to Cleff \& Cleff (2014), if the research data is too large, the normality test can be ignored.

\section{Multicollinearity}

Multicollinearity testing in the regression model is done by looking at the VIF Tolerance value of the regression output (Hidayat, 2011). VIF values more significant than ten or tolerance less than 0.1 indicate there are symptoms of multicollinearity in the regression model. VIF values and tolerance of each independent variable are obtained as follows.

The test results show that there is no VIF value of a variable that has a value of more than 10 . The regression model does not have a multicollinear problem.

\section{Autocorrelation}

Autocorrelation testing was performed using the Durbin Watson test. 
Durbin Watson's value which is between the value of du and 4-du shows a model that is not affected by autocorrelation problems. On the autocorrelation, test results showed a DW value of 0.013 indicates that the occurrence of autocorrelation. For that, the data is transformed by using Lag.

After transforming the DW value obtained is 1.740 . Table $\mathrm{dU}$ values for $\mathrm{k}=$ 3 and 2033 data obtained at 1.74 . Thus the DW value in the model is in the area between $\mathrm{dU}=$ (1.73) and 4-du (2.26), which means there is no autocorrelation.

These results indicate that the stock price index ( $\left.\mathrm{Ln} \_\mathrm{X} 1\right)$, the exchange rate of IDR / USD (Ln_X2) and the price of gold (Ln_X3) have a positive effect on the price of Bitcoin.

The adjusted $\mathrm{R}^{2}$ value of 0.686 (Table 7) means that $68.6 \%$ of the variation in the price of Bitcoin can be explained by variations in the three independent variables (Stock Index, IDR / USD Exchange Rate and Gold Price) while other independent variables influence the rest.
ANOVA test results or $\mathrm{F}$ tests show an $\mathrm{F}$ count with a significance level of 0.000 or less than 0.05 . It shows that the regression model can be used to predict the price of Bitcoin or the three independent variables affects the price of Bitcoin.

\section{Multiple Linear Regression Results}

The output of multiple linear regression gives the following results:

$$
\begin{aligned}
\operatorname{Ln} \_Y= & -170,306+9,217 \operatorname{Ln}_{X_{1}}+ \\
& 7,053 \operatorname{Ln}_{X_{2}}+3,098 \operatorname{Ln}_{-} X_{3}+e
\end{aligned}
$$

These results indicate that the stock price index (Ln_X1), the exchange rate of IDR / USD (Ln_X2) and the price of gold (Ln_X3) have a positive effect on the price of Bitcoin.

T-test results for all independent variables have a significance level below 0.05 (Table 8). It means that each independent variable individually also significantly influences the price of Bitcoin.

Normal P-P Plot of Regression Standardized Residual

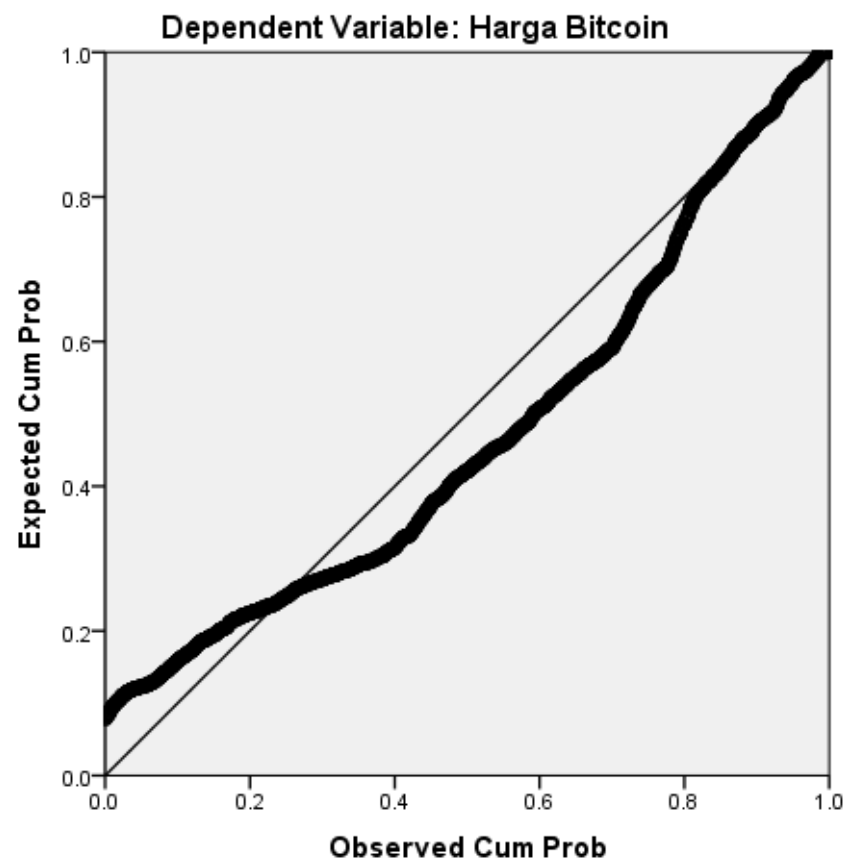

Figure 2. P-P Plot Normality Test 
Table 3. Kolmogorov - Smirnov Normality Test

\begin{tabular}{|c|c|c|}
\hline & & d Residual \\
\hline $\mathrm{N}$ & & 2068 \\
\hline Normal Parameters ${ }^{a, b}$ & Mean & .0000000 \\
\hline & Std.Deviation & .91618663 \\
\hline Most Extreme Differences & Absolute & .084 \\
\hline & Positive & .084 \\
\hline & Negative & -.051 \\
\hline Test Statistics & & .084 \\
\hline Asymp. Sig. (2-tailed) & & $.000^{\mathrm{c}}$ \\
\hline
\end{tabular}

a.Test distribution is normal

b.Calculated from data

c.Lilliefors Significance Correction

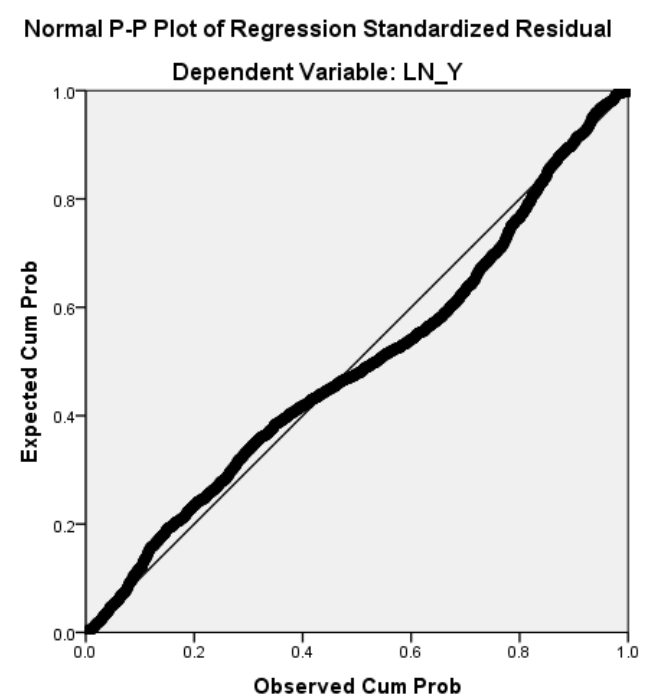

Figure 3. P-P Normality Test Second Plot

Table 4. Second Normality Test

\begin{tabular}{llr}
\hline & & Unstandardized Residual \\
\hline $\mathrm{N}$ & & 2033 \\
Normal Parameters & Mean & .0000000 \\
& Std.Deviation & .84958624 \\
Most Extreme Differences & Absolute & .074 \\
& Positive & .074 \\
& Negative & -.041 \\
Test Statistics & & .074 \\
Asymp. Sig. (2-tailed) & & $.000^{\text {c }}$ \\
\hline a.Test distribution is normal & & \\
b.Calculated from data & & \\
c.Lilliefors Significance Correction & &
\end{tabular}

Table 5. Multicollinearity Test

\begin{tabular}{|c|c|c|c|}
\hline & & \multicolumn{2}{|c|}{ Collinearity Statistics } \\
\hline Model & & Tolerance & VIF \\
\hline \multirow[t]{3}{*}{1} & LN X1 & .234 & 4.267 \\
\hline & LN_X2 & .303 & 3.303 \\
\hline & LN_X3 & .386 & 2.590 \\
\hline
\end{tabular}


Table 6. Autocorrelation Testing

\begin{tabular}{|c|c|c|c|c|c|}
\hline Model & $\mathrm{R}$ & R Square $^{b}$ & $\begin{array}{c}\text { Adjusted R } \\
\text { Square }\end{array}$ & $\begin{array}{l}\text { Std. Error of } \\
\text { the estimate }\end{array}$ & $\begin{array}{l}\text { Durbin- } \\
\text { Watson }\end{array}$ \\
\hline 1 & $.964^{\mathrm{a}}$ & .929 & .929 & .85021 & .013 \\
\hline
\end{tabular}

Table 7. Second Autocorrelation Testing

\begin{tabular}{lcrrrc}
\hline Model & $\mathrm{R}$ & R Square $^{\mathrm{b}}$ & $\begin{array}{c}\text { Adjusted R } \\
\text { Square }\end{array}$ & $\begin{array}{c}\text { Std. Error of } \\
\text { the estimate }\end{array}$ & $\begin{array}{c}\text { Durbin- } \\
\text { Watson }\end{array}$ \\
\hline 1 & $.828^{\mathrm{a}}$ & .686 & .686 & .06188 & 1.740 \\
\hline
\end{tabular}

a.Predictors: Lag_X3Ln, Lag_X1Ln, Lag_X2Ln

Table 8. Regression Output

Coefficients $^{\mathrm{a}}$

\begin{tabular}{rlrrrrr}
\hline \multirow{2}{*}{ Model } & \multicolumn{2}{c}{ Unstandardized Coefficients } & $\begin{array}{l}\text { Standardized } \\
\text { Coefficients }\end{array}$ & t & Sig. \\
\cline { 3 - 5 } & \multicolumn{1}{c}{ B } & \multicolumn{1}{c}{ Std. Error } & \multicolumn{1}{c}{ Beta } & \\
\hline 1 & (Constant) & -170.306 & 2.580 & & -66.014 & .000 \\
& LN_X1 & 9.217 & .236 & .506 & 39.095 & .000 \\
& LN_X2 & 7.053 & .200 & .400 & 35.238 & .000 \\
& LN_X3 & 3.098 & .278 & .114 & 11.153 & .000 \\
\hline
\end{tabular}

a. Dependent Variable: LN_Y

Table 9. Testing the Fit Model (ANOVA)

\begin{tabular}{llrrrrr}
\hline Model & & Sum of Squares & \multicolumn{1}{c}{ df } & Mean Square & F & Sig. \\
\hline 1 & Regression & 19217.107 & 3 & 6405.702 & 8755.657 & $.000^{\mathrm{b}}$ \\
& Residual & 1486.626 & 2032 & .732 & & \\
& Total & 20703.733 & 2035 & & & \\
\hline
\end{tabular}

a. Dependent Variable: LN_Y

b. Predictors: (Constant), LN_X3, LN_X2, LN_X1

\section{Discussion}

The results of $t$ arithmetic for the Stock Price Index (Ln_X1), the exchange rate (Ln_X2) and the price of gold (Ln_X3) give the results of $t$ 39,095, 35,238 and 11,153 with a significance level of 0,000 (less than 0.05).

Thus Ho for the three hypotheses of this study was rejected. It means that the Stock Price Index, Rupiah exchange rate, and gold prices influence the Bitcoin Price. An increase (decrease) in the three commodities will be followed by an increase (decrease) in the price of Bitcoin.

Investors seem to see that both stocks, exchange rates, and gold and Bitcoin are assets that are positively interconnected. Senior market analyst at eToro, Mati Greenspan, once stated that the correlation of the price of Bitcoin with gold has become significant compared to the previous time. In August 2019, Bloomberg released a report that the correlation between Bitcoin and gold rose to close to 1 (perfect). It shows that Bitcoin is starting to be more integrated with money markets and capital markets. Bitcoin has been accepted as an asset worthy of an investment portfolio.

It is an exciting fact because Bitcoin has no intrinsic value. How can an instrument that has no intrinsic value become an investment choice? According to Kristoufek (2013), this phenomenon cannot be explained by traditional financial 
theories which assume that humans are rational.

Thus, an explanation of this phenomenon is more appropriate when using a behavioural perspective or behavioural finance, as stated by Lehman (2017) and Yang (2018). Behavioural finance is one of the mainstream in economics that combines psychology and economics. This approach can explain why people make irrational decisions, as happened to victims of bulging investment (Hidajat, 2018).

In behavioural finance, humans are normal creatures (Statman, 2014). According to Statman (2005), irrational (normal) investors are investors who are influenced by emotional biases and cognitive emotions. Emotional bias is to use feelings or emotions in making decisions. It is considered as a bias because it ignores information or facts that should be processed correctly and objectively. Fear and greed in making decisions is wrong proof that that emotional factors influence the way of thinking and acting Shefrin (2002). Cognitive bias is to use the rule of thumb in making decisions. Cognitive bias occurs when people process and interpret information around them. The way a person remembers an event can be biased for several reasons and in turn can lead to biased decision making.

The implication of this is that decision making in Bitcoin investments or transactions is inseparable from the emotional and cognitive aspects. These two factors are the answers that can explain precisely why Bitcoin has become a popular instrument.

\section{CONCLUSION AND RECOMMEN- DATION}

Stock price index, IDR / USD exchange rate, and gold price have a positive effect on the price of Bitcoin. Changes will follow changes that occur in all three variables in the price of Bitcoin in the same direction. Bitcoin has been considered the same as shares, currencies, and gold as investment instruments or assets that are worth having.

This study uses all daily IDX Composite data, IDR / USD exchange rates, gold prices and bitcoin prices for the period July 2010 - December 2018, researchers should add some variables such as comparing with stock indices and other countries' exchange rates. It is hoped that the next researcher will divide the data in the long and short term so that the influence between variables is adequately seen.

\section{REFERENCES}

Baur, D. G., Dimpfl, T., \& Kuck, K. (2018). Bitcoin, gold and the US dollar - A replication and extension. Finance Research Letters, 25, 103110. https://doi.org/10.1016/j.frl.2017.10.0 12

Baur, D. G., Hong, K. H., \& Lee, A. D. (2018). Bitcoin: Medium of exchange or speculative assets? Journal of International Financial Markets, Institutions and Money, 54, 177-189. https://doi.org/10.1016/j.intfin.2017.1 2.004

Cleff, T., \& Cleff, T. (2014). Univariate Data Analysis. In Exploratory Data Analysis in Business and Economics. https://doi.org/10.1007/978-3-31901517-0_3

Darmawan, O. (2014). Bitcoin Mata Uang Digital Dunia. Jakarta: Jasakom.

Dyhrberg, A. H. (2016). Bitcoin, gold and the dollar - A GARCH volatility analysis. Finance Research Letters, 16 , 85-92. https://doi.org/10.1016/j.frl.2015.10.0 08

Hidajat, T. (2018). Financial Literacy, Ponzi and Pyramid Scheme in Indonesia. Jurnal Dinamika Manajemen, 9(2), 198-205. 
Hidayat, T., \& Istiadah, N. (2011).

Panduan lengkap menguasai SPSS 19 untuk mengolah data statistik penelitian. Jakarta: Mediakita.

Kristoufek, L. (2015). What are the main drivers of the bitcoin price? Evidence from wavelet coherence analysis. PLoS ONE, 10(4), 1-15. https://doi.org/10.1371/journal.pone.0 123923

Kurihara, Y., \& Fukushima, A. (2018). How Does Price of Bitcoin Volatility Change? International Research in Economics and Finance, 2(1), 8. https://doi.org/10.20849/iref.v2i1.317

Lehman, R. (2017). A Behavioral Finance View of Cryptocurrencies. Retrieved from

https://www.behavioralfinance.com/bi tcoin-behavior/2017/12/13/a-

behavioral-finance-view-ofcryptocurrencies

Murtini, U., Amijoyo, S. K., Bisnis, F., Kristen, U., \& Wacana, D. (2001). PENGARUH PERUBAHAN HARGA EMAS DUNIA DAN. 139145.

Nakamoto, S. (2008). Bitcoin: a peer-topeer electronic cash system (2008).

Shefrin, H. (2002). Beyond greed and fear: Understanding behavioral finance and the psychology of investing. Oxford University Press on Demand.

Smith, J. (2018). An Analysis of Bitcoin Exchange Rates. SSRN Electronic Journal.

https://doi.org/10.2139/ssrn.2493797

Statman, M. (2005). Normal Investors, Then and Now. Financial Analysts Journal, 61(2), 31-37.

Sukamulja, S., \& Sikora, C. O. (2018). the New Era of Financial Innovation: the Determinants of Bitcoin'S Price. Journal of Indonesian Economy and Business, 33(1), 46. https://doi.org/10.22146/jieb.30646 van Wijk, D. (2013). What can be expected from the Bitcoin. Erasmus Universiteit Rotterdam. Retrieved from

file:///C:/Users/ioaro/AppData/Local/ Temp/Final-version-Thesis-Dennisvan-Wijk.pdf

Wang, J., Xue, Y., \& Liu, M. (2016). An Analysis of Bitcoin Price Based on VEC Model. (Icemi), 146-152. https://doi.org/10.2991/icemi16.2016 .36

Whelan, K. (2013). How is bitcoin different from the dollar. Forbes. November 19th. URL: Http://Www. Forbes.

Com/Sites/Karlwhelan/2013/11/19/H ow-Isbitcoin-Different-from-theDollar/.(Collected: 2018-08-22).

Yang, H. (2018). Behavioral Anomalies in Cryptocurrency Markets. SSRN Electronic Journal. Available at: Https://Ssrn.Com/Abstract=3174421. https://doi.org/https://dx.doi.org/10.21 39/ssrn.3174421

Yermack, D. (2015). Is Bitcoin a Real Currency? An Economic Appraisal. In Handbook of Digital Currency: Bitcoin, Innovation, Financial Instruments, and Big Data. https://doi.org/10.1016/B978-0-12802117-0.00002-3

Zhu, Y., Dickinson, D., \& Li, J. (2017). Analysis on the influence factors of Bitcoin's price based on VEC model. Financial Innovation, 3(1). https://doi.org/10.1186/s40854-0170054-0 